\title{
Characteristics of Microclimate in Three Forest Stands Monitored by Meteorological Sensor Array
}

\author{
Byoung-Koo Choi ${ }^{\dagger}$ and Hee Mun Chae ${ }^{* \dagger}$ \\ Division of Forest Science, College of Forest and Environment Sciences, Kangwon National University, \\ Chuncheon 24341, Republic of Korea \\ (Received July 19, 2019; accepted October 23, 2019)
}

Keywords: coniferous forest stands, weather station, meteorological factors

In this study, we analyzed the characteristics of microclimate in three types of coniferous forest stand in mountainous areas of Korea, categorized as Pinus densiflora Siebold \& Zucc. (PD), Pinus koraiensis Siebold \& Zucc. (PK), and Larix kaempferi (Lamb.) Carrière (LK). Climate data were obtained using a HOBO data logger installed in each forest stand, and meteorological factors were compared between forest land and nonforest land (weather stations) from July 2015 to May 2017. The differences in daily mean temperature, daily mean maximum temperature, daily mean minimum temperature, and daily mean relative humidity between three study sites and weather stations were significant, except for the daily mean temperature difference at the PD site. The meteorological differences between forest areas and weather stations reflect different forest characteristics such as forest type and tree density. The results also indicate that, even if the same tree species is planted in a forest area, the effects of the microclimate can vary depending on the environmental characteristics of the forest stand such as elevation, slope, and latitude.

\section{Introduction}

Climate affects the structure and function of forest ecology, and all components in the forest ecosystem are directly or indirectly affected by climatic conditions. Changes in meteorological factors on the forest ecosystem have direct physiological effects and an indirect effect on the interactions between multiple organisms. Therefore, systematic research into meteorological factors is required to analyze the environmental changes of forest ecosystem vegetation.

Meteorological conditions such as temperature, humidity, precipitation, and solar radiation are important factors for analyzing the status index of Korean oak (Quercus acutissima). ${ }^{(1)}$ Soil temperature, which affects the development, growth, survival, and microbial activity of forest ecosystems, is also closely related to atmospheric moisture and solar radiation in the forest. Soil temperature also increases with atmospheric temperature. ${ }^{(2)}$ Climatic factors such as temperature and relative humidity are also key environmental factors in forests, and

\footnotetext{
*Corresponding author: e-mail: cheemun@kangwon.ac.kr

${ }^{\dagger}$ These authors contributed equally to this work.

https://doi.org/10.18494/SAM.2019.2536
} 
climatic changes play an important role in ecological phenomena, species distribution, species composition and diversity, and vegetation reproduction and productivity. ${ }^{(3,4)}$

Because small-scale microclimate changes play an important role in the ecological and physiological effects of vegetation, ${ }^{(5,6)}$ the collection and analysis of microclimate data are vital for ecosystem management. ${ }^{(7)}$ In general, the microclimate is divided into small-scale units, which range from 0.01 to $1000 \mathrm{~m},{ }^{(8)}$ but the microclimate range of forest ecosystems can be affected by topographic characteristics, forest type, forest aspect, and so forth; therefore, various changes occur within this range. Furthermore, the temperature within a forest ecosystem strongly affects vegetation cover. Typically, the local climate of a below-canopy forest maintains low temperatures and low wind speeds. Moreover, the temperature decrease during the night is lower in forest areas than in nonforest areas, as forests mitigate the atmospheric temperature during the day. ${ }^{(9-13)}$ Tree crowns in forest ecosystems have unique microclimate characteristics in that they reduce solar radiation, the daytime air temperature on sunny days, and wind speed, and increase humidity. These microclimate differences are important for the structure and function of the entire forest and have a significant impact on forest ecology, biodiversity, and ecosystem processes. ${ }^{(11,14)}$ Moreover, they are affected by exposure to the sun or wind (velocity and direction), rainfall, temperature (atmospheric and soil), and humidity from the atmosphere. ${ }^{(15)}$ Thus, it is important to investigate the interrelationships between climate variability and factors such as vegetation type and forest density to understand the climatic impacts on forest ecosystems.

Climatic changes in forest ecosystems lead to positive changes in some species and adverse changes in other species, which can alter the interactions between species and eventually change the species composition of the ecosystem. ${ }^{(16)}$ The changes in temperature in forest land are associated with land use and land cover changes. ${ }^{(17)}$ Land surface temperature tends to increase with decreasing vegetation area. ${ }^{(18)}$ Changes in meteorological factors such as temperature can affect photosynthesis, respiration, tree growth rate, and forest productivity. ${ }^{(19)}$ Therefore, research into current climatic changes in forest ecosystems could also be an important input of future species composition and forest productivity.

In Korea, various tree species have been planted in mountainous areas for forest reforestation since the 1970s. Three conifer species, namely, Pinus densiflora Siebold \& Zucc. (PD), Pinus koraiensis Siebold \& Zucc. (PK), and Larix kaempferi (Lamb.) Carrière (LK), are important tree planting species in Korea. The total area of coniferous forest in Korea is 2339022 ha consisting of PD (1562843 ha), PK (170905 ha), and LK (259355 ha), according to the Forestry Statistical Yearbook published by the Korea Forest Service. ${ }^{(20)}$ There are very few studies on the relationship between tree growth and climate factors. In particular, this study was intended to analyze changes in microclimatic characteristics in forests already established in mountain areas of Korea. Therefore, in this study, we analyze the seasonal and monthly meteorological differences and meteorological characteristics of three different conifer forest stands according to geographical differences. In addition, we compare meteorological factors in both the forest stands and the nonforest areas, i.e., weather stations of the Korea Meteorological Administration. 


\section{Materials and Methods}

\subsection{Study area}

In the total area of Korea, forest areas occupy approximately $64 \%$ and most are located in mountainous terrain. A study area was selected in a mountainous terrain of Korea for the analysis of the meteorological characteristics of three coniferous forest species: PD, PK, and LK (Fig. 1 and Table 1). We used data from weather stations near sites 1, 4, and 6 to compare meteorological factors between forest areas (also sites 1, 4, and 6) and nonforest areas (weather stations of the Korea Meteorological Administration). The meteorological data of weather stations were collected from the Korea Meteorological Administration. ${ }^{(21)}$

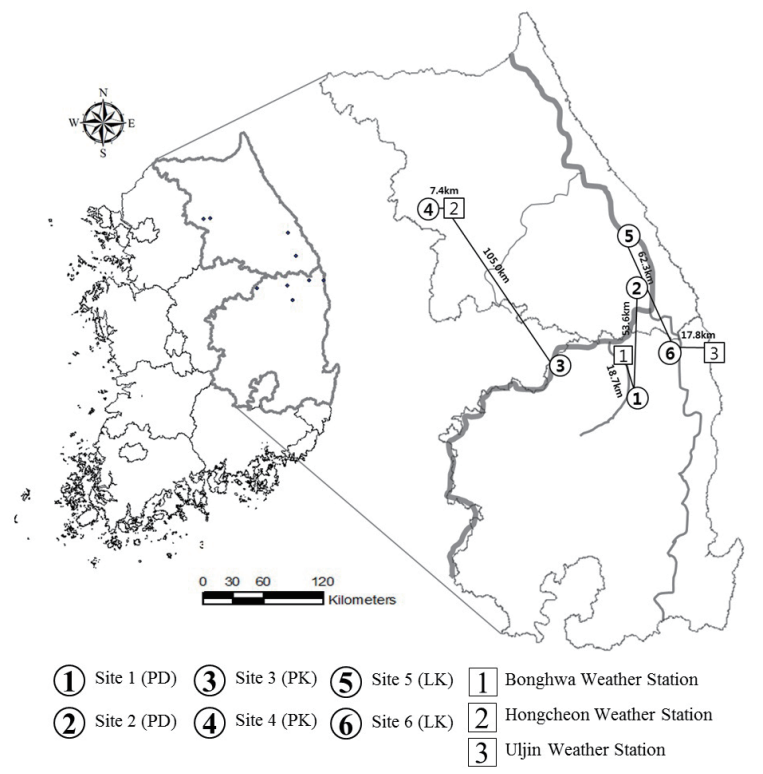

Fig. 1. Map of the six study sites and three weather stations used for measurement of meteorological factors in Korea.

Table 1

Description and characteristics of six study sites used in this study.

\begin{tabular}{lcccccccc}
\hline $\begin{array}{l}\text { Study } \\
\text { site }\end{array}$ & $\begin{array}{c}\text { Forest } \\
\text { stand }\end{array}$ & $\begin{array}{c}\text { Tree age } \\
(\text { year })\end{array}$ & $\begin{array}{c}\text { Altitude } \\
(\mathrm{m})\end{array}$ & $\begin{array}{c}\text { Tree } \\
(\mathrm{ha})\end{array}$ & $\begin{array}{c}\text { Aspect } \\
\left({ }^{\circ}\right)\end{array}$ & $\begin{array}{c}\text { Slope } \\
\left({ }^{\circ}\right)\end{array}$ & $\begin{array}{c}\text { Measurement } \\
\text { start date }\end{array}$ & Location (GPS) \\
\hline Site 1 & PD & 47 & 432 & 320 & 210 & 19 & 2015.07. & $\begin{array}{c}\text { Latitude: } 36.7845470 \\
\text { Longitude: } 28.9812830\end{array}$ \\
\hline Site 2 & PD & 45 & 601 & 525 & 156 & 8 & 2015.10. & $\begin{array}{c}\text { Latitude: } 37.2651860 \\
\text { Longitude: } 29.0384750\end{array}$ \\
\hline Site 3 & PK & 37 & 495 & 600 & 230 & 18 & 2015.07. & $\begin{array}{c}\text { Latitude: } 36.9256503 \\
\text { Longitude: } 28.5053560\end{array}$ \\
\hline Site 4 & PK & 38 & 380 & 570 & 216 & 18 & 2015.07. & $\begin{array}{c}\text { Latitude: } 37.6795429 \\
\text { Longitude: } 27.7965609\end{array}$ \\
\hline Site 5 & LK & 40 & 712 & 450 & 340 & 13 & 2016.08. & $\begin{array}{c}\text { Latitude: } 37.5166049 \\
\text { Longitude: } 28.9405539\end{array}$ \\
\hline Site 6 & LK & 54 & 474 & 775 & 354 & 30 & 2015.07. & $\begin{array}{c}\text { Latitude: } 36.9992249 \\
\text { Longitude: } 29.2129459\end{array}$ \\
\hline
\end{tabular}


Sites 1 and 2 are PD forest stand areas. Site 1 has an altitude of $432 \mathrm{~m}$, an aspect of $210^{\circ}$, a slope of $19^{\circ}$, and a tree density of 320 trees/ha. At site 2 , the altitude is $601 \mathrm{~m}$, the aspect is $156^{\circ}$, the slope is $8^{\circ}$, and the tree density is 525 trees/ha. The distance between sites 1 and 2 is $53.6 \mathrm{~km}$, with site 1 located further north. Site 2 is in the east coast region of Korea, which has an oceanic climate. Sites 3 and 4 are PK forest stand areas. The distance between sites 3 (495 $\mathrm{m}$ altitude, $230^{\circ}$ aspect, $18^{\circ}$ slope, 600 trees $/ \mathrm{ha}$ ) and 4 (380 $\mathrm{m}$ altitude, $216^{\circ}$ aspect, $18^{\circ}$ slope, 570 trees/ha) is $105 \mathrm{~km}$, with site 4 located further north. Site 4 is the most northern site and has the lowest temperature among the survey areas. Sites 5 and 6 are LK forest stand areas. The distance between sites 5 ( $712 \mathrm{~m}$ altitude, $340^{\circ}$ aspect, $13^{\circ}$ slope, 450 trees $/$ ha) and 6 (474 m altitude, $354^{\circ}$ aspect, $30^{\circ}$ slope, 775 trees $/$ ha) is $62.3 \mathrm{~km}$, with site 5 located further north. These two sites are located in the east coast region of Korea, which has an oceanic climate.

\subsection{Measurement of microclimate conditions in the three conifer stands}

HOBO data loggers (U12-012) were set up at the six study sites (Table 1 and Fig. 1) for the measurement of microclimate conditions and temperature $\left(\mathrm{T},{ }^{\circ} \mathrm{C}\right)$ in the three conifer stands. Relative humidity (RH, \%) and light intensity (LI, lux) were measured every hour during the study period. The measured meteorological data were downloaded directly from each HOBO data logger each month to analyze meteorological differences by species and location using monthly mean values from each species. The HOBO data logger used for this study has internal $\mathrm{T}$, LI, and RH sensors on a 4 inch wire mounted on the circuit board inside the snap lid case. The T sensor has a range from -40 to $+120{ }^{\circ} \mathrm{C}$ with an accuracy of $\pm 0.7^{\circ} \mathrm{C}$ at $21{ }^{\circ} \mathrm{C}$. The $\mathrm{RH}$ sensor range is 25 to $95 \%$ with an accuracy of $\pm 5 \%$. The nominal range of the LI sensor is 22 to 3229 lux, although maximum values can vary from 6458 to 9688 lux. A small instrument $(15 \times 15$ $\mathrm{cm}^{2}$, height $1 \mathrm{~m}$ ) was made to measure the microclimate conditions in the forest stand, and a HOBO data logger was inserted into this instrument and installed in each study site (Fig. 2).

Measurements of meteorological factors at sites 1 (PD), 3 (PK), 4 (PK), and 6 (LK) began in July 2015 and ended in May 2017. Site 2 (PD) measurements started in October 2015 and ended

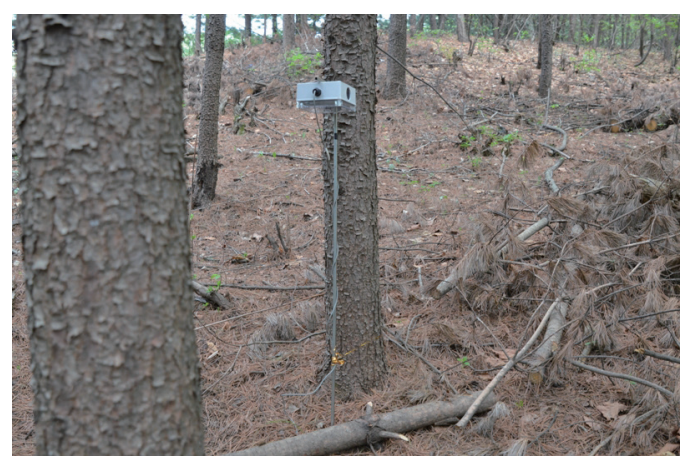

(a)

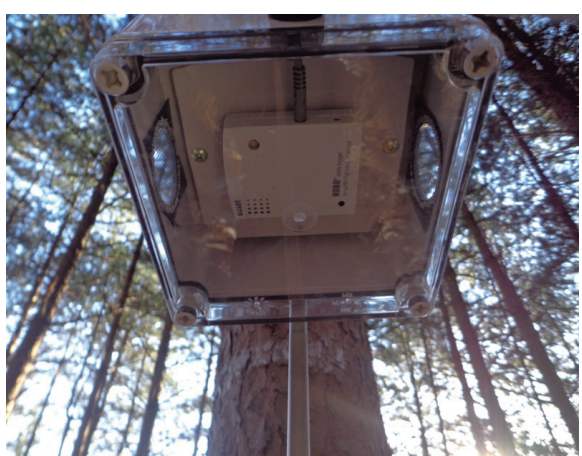

(b)

Fig 2. (Color online) HOBO data logger installed at site 6 (PK forest stand) as the instrument $\left(15 \times 15 \mathrm{~cm}^{2}\right.$, height $1 \mathrm{~m}$ ) for measuring micro-meteorological factors. 
in May 2017, and site 5 (LK) measurements started in August 2016 and ended in May 2017. The meteorological data from weather stations close to the study sites were used to compare meteorological factors in forest and nonforest areas. The weather station adjacent to site 1 (18.7 km distance) was Bonghwa Weather Station, that adjacent to site 4 (7.4 km distance) was Hongcheon Weather Station, and that adjacent to site 6 (17.8 $\mathrm{km}$ distance) was Uljin Weather Station (Fig. 1). The analysis of meteorological data was performed using the SPSS (IBM SPSS Statistics 24) program. The Wilcoxon rank-sum test was used to test daily, monthly, and annual means and variances for weather factors to compare each meteorological factor between forest stands and weather stations. ${ }^{(22)}$

\section{Results and Discussion}

\subsection{Comparison of meteorological factors between forest and nonforest areas}

The monthly mean temperatures $\left({ }^{\circ} \mathrm{C}\right)$, monthly mean relative humidities (\%), and monthly mean light intensity (lux) roughnesses at sites 1 (PD), 4 (PK), and 6 (LK) and the corresponding weather stations are shown in Table 2. The light intensities at each study site and weather station were not compared because the Korean weather stations did not provide daily light intensity data.

At both sites 4 and 6 , during the study period, the mean temperatures $\left({ }^{\circ} \mathrm{C}\right)$ were lower than those at the weather stations, and the mean relative humidities (\%) were higher. Thus, the mean temperature was lower in forest areas than in nonforest areas, and the mean relative humidity was higher in forest areas than in nonforest areas. These results reflect the characteristics of the forest area, that is, the intensity and trend of micrometeorology depend on the forest type, structure, and cover. $^{(23)}$ Site 1 showed the same relative humidity trend; however, the mean temperatures at both the site (forest area) and the weather station (nonforest area) were similar in 2015, 2016, and 2017. This is because the site has a southern aspect and a low density of trees (Table 1).

The mean relative humidities at the weather stations were similar to those at the study sites. However, the mean temperature at Uljin Weather Station (site 6) was the highest because of its location in the oceanic climate area in the east of Korea. Hongcheon Weather Station (site 4) is the most northern of the three study sites, but the mean temperature at this station is higher than that at Bonghwa Weather Station (site 1). This may be due to the difference in area where the weather station was located; Bonghwa Weather Station is located closer to a mountainous area than Hongcheon Weather Station (Table 1 and Fig. 1).

The daily mean temperature differences between the study sites and the weather stations (Wilcoxon rank-sum test: $Z=-19.823, P=0.000$ in site 4 and $Z=-19.650, P=0.000$ in site 6) were significant except for site 1 . The differences in daily mean relative humidity between the study sites and the weather stations $(Z=-15.873, P=0.000$ in site $1, Z=-21.66, P=0.000$ in site 4 , and $Z=-19.21, P=0.000$ in site 6 ) were significant (Table 3). The climatic differences between the forest areas and the weather stations are considered to reflect the characteristics of forests such as forest canopy and forest vegetation type. 
Table 2

Comparison of weather factors at the three forest sites and weather stations during the study period.

\begin{tabular}{|c|c|c|c|c|c|c|c|c|c|c|c|c|c|c|c|c|}
\hline \multirow[b]{3}{*}{$\mathrm{r}$} & \multirow[b]{3}{*}{ Month } & \multicolumn{5}{|c|}{ Site 1} & \multicolumn{5}{|c|}{ Site 4} & \multicolumn{5}{|c|}{ Site 6} \\
\hline & & \multicolumn{3}{|c|}{$\begin{array}{l}\text { Forest area } \\
\text { (PD) }\end{array}$} & \multicolumn{2}{|c|}{$\begin{array}{c}\text { Weather } \\
\text { station (PD) }\end{array}$} & \multicolumn{3}{|c|}{$\begin{array}{l}\text { Forest area } \\
\text { (PK) }\end{array}$} & \multicolumn{2}{|c|}{$\begin{array}{c}\text { Weather } \\
\text { station (PK) }\end{array}$} & \multicolumn{3}{|c|}{$\begin{array}{l}\text { Forest area } \\
\text { (LK) }\end{array}$} & \multicolumn{2}{|c|}{$\begin{array}{c}\text { Weather } \\
\text { station (LK) }\end{array}$} \\
\hline & & $\begin{array}{c}\mathrm{T} \\
\left({ }^{\circ} \mathrm{C}\right)\end{array}$ & $\begin{array}{l}\mathrm{RH} \\
(\%)\end{array}$ & $\begin{array}{c}\text { LI } \\
\text { (lux) }\end{array}$ & $\begin{array}{c}\mathrm{T} \\
\left({ }^{\circ} \mathrm{C}\right) \\
\end{array}$ & $\begin{array}{l}\mathrm{RH} \\
(\%)\end{array}$ & $\begin{array}{c}\mathrm{T} \\
\left({ }^{\circ} \mathrm{C}\right)\end{array}$ & $\begin{array}{l}\mathrm{RH} \\
(\%)\end{array}$ & $\begin{array}{c}\text { LI } \\
\text { (lux) }\end{array}$ & $\begin{array}{c}\mathrm{T} \\
\left({ }^{\circ} \mathrm{C}\right)\end{array}$ & $\begin{array}{l}\mathrm{RH} \\
(\%)\end{array}$ & $\begin{array}{c}\mathrm{T} \\
\left({ }^{\circ} \mathrm{C}\right) \\
\end{array}$ & $\begin{array}{l}\mathrm{RH} \\
(\%)\end{array}$ & $\begin{array}{c}\text { LI } \\
\text { (lux) }\end{array}$ & $\begin{array}{c}\mathrm{T} \\
\left({ }^{\circ} \mathrm{C}\right)\end{array}$ & $\begin{array}{l}\mathrm{RH} \\
(\%)\end{array}$ \\
\hline \multirow{7}{*}{2015} & July & 23.5 & 84.1 & 118.9 & 22.2 & 81.0 & 21.1 & 83.9 & 15.3 & 24.8 & 73.0 & 20.5 & 88.0 & 41.1 & 22.2 & 82.0 \\
\hline & August & 22.3 & 85.3 & 116.5 & 22.2 & 82.0 & 21.8 & 55.5 & 12.3 & 25.4 & 75.0 & 21.2 & 90.3 & 35.7 & 24.3 & 82.0 \\
\hline & September & 17.3 & 80.6 & 110.0 & 17.0 & 75.0 & 17.3 & 76.0 & 17.6 & 19.6 & 70.0 & 15.6 & 92.8 & 27.5 & 19.5 & 81.0 \\
\hline & October & 12.1 & 70.5 & 153.4 & 10.9 & 71.0 & 11.9 & 71.8 & 18.2 & 13.1 & 69.0 & 10.6 & 78.8 & 45.6 & 15.3 & 64.0 \\
\hline & Nove & 7.1 & 86.1 & 89.1 & 7.2 & 79.0 & 5.6 & 86.0 & 36.5 & 7.7 & 81.0 & 6.1 & 87.5 & 76.1 & 10.3 & 75.0 \\
\hline & Dec & 0.1 & 78.2 & 115.3 & 0.1 & 71.0 & -1.1 & 74.7 & 42.9 & -0.1 & 71.0 & 0.0 & 77.6 & 127.0 & 5.3 & 59.0 \\
\hline & Mean & 13.7 & 80.8 & 117.2 & 13.3 & 76.5 & 12.8 & 74.7 & 23.8 & 15.1 & 73.2 & 12.3 & 85.8 & 58.8 & 16.2 & 73.8 \\
\hline \multirow{13}{*}{2016} & Janu & -4.5 & 63.4 & 144.3 & -4.3 & 55.0 & -6.1 & 65.6 & 43.2 & -4.7 & 56.0 & -4.6 & 62.8 & 223.1 & 0.8 & 44.0 \\
\hline & Februar & -1.0 & 60.8 & 196.4 & -1.6 & 54.0 & -2.7 & 76.5 & 63.9 & -1.1 & 56.0 & -1.9 & 66.0 & 390.1 & 2.6 & 54.0 \\
\hline & March & 4.8 & 61.5 & 252.1 & 4.2 & 59.0 & 3.9 & 70.3 & 63.5 & 5.8 & 52.0 & 3.6 & 68.9 & 386.3 & 7.1 & 61.0 \\
\hline & April & 11.8 & 65.4 & 333.7 & 11.3 & 61.0 & 11.3 & 66.0 & 48.9 & 13.8 & 53.0 & 10.7 & 68.6 & 360.4 & 12.5 & 68.0 \\
\hline & May & 16.6 & 61.9 & 284.7 & 16.3 & 57.0 & 16.0 & 72.1 & 37.9 & 18.7 & 58.0 & 15.4 & 65.2 & 102.8 & 16.6 & 67.0 \\
\hline & June & 20.4 & 73.5 & 167.4 & 20.7 & 61.0 & 19.5 & 80.2 & 27.9 & 23.1 & 65.0 & 18.9 & 79.6 & 68.0 & 20.4 & 80.0 \\
\hline & July & 22.7 & 91.5 & 112.5 & 23.2 & 79.0 & - & - & - & - & - & 21.4 & 94.2 & 36.4 & 23.0 & 88.0 \\
\hline & Augu & 23.3 & 83.4 & 140.2 & 23.7 & 77.0 & 22.5 & 87.6 & 10.2 & 26.6 & 72.0 & 21.3 & 90.1 & 28.7 & 24.9 & 84.0 \\
\hline & Septe & 18.5 & 91.0 & 79.4 & 19.1 & 83.0 & 17.9 & 89.1 & 8.8 & 21.0 & 78.0 & 17.2 & 94.2 & 10.3 & 20.6 & 87.0 \\
\hline & Octo & 12.8 & 88.9 & 97.3 & 13.0 & 82.0 & 12.2 & 82.2 & 8.7 & 14.3 & 77.0 & 11.4 & 93.4 & 19.6 & 15.6 & 79.0 \\
\hline & November & 4.8 & 77.8 & 113.8 & 4.5 & 73.0 & 4.1 & 71.6 & 14.9 & 5.1 & 67.0 & 4.2 & 82.7 & 77.8 & 9.1 & 66.0 \\
\hline & Dece & -0.1 & 78.5 & 124.8 & 0 & 69.0 & -1.2 & 78.2 & 49.4 & -0.5 & 72.0 & 0.1 & 75.0 & 105.4 & 5.5 & 57.0 \\
\hline & Mean & 10.8 & 74.8 & 170.6 & 10.8 & 67.5 & 8.9 & 76.3 & 34.3 & 11.1 & 64.2 & 9.8 & 78.4 & 150.7 & 13.2 & 69.6 \\
\hline \multirow{5}{*}{2017} & Janu & -3.2 & 68.2 & 200.0 & -3.2 & 59.0 & -4.4 & 69.6 & 63.6 & -3.7 & 62.0 & -3.6 & 68.8 & 254.7 & 2.1 & 50.0 \\
\hline & February & -1.2 & 61.3 & 206.3 & -0.9 & 54.0 & -2.9 & 67.5 & 109.2 & -1.6 & 57.0 & -1.3 & 62.8 & 180.3 & 3.6 & 48.0 \\
\hline & March & 3.8 & 62.1 & 250.7 & 3.7 & 57.0 & 3.1 & 60.5 & 26.7 & 4.7 & 53.0 & 2.3 & 70.1 & 254.8 & 6.6 & 62.0 \\
\hline & April & 11.1 & 64.6 & 338.1 & 11.4 & 59.0 & 11.0 & 59.2 & 36.3 & 13.1 & 51.0 & 10.3 & 66.5 & 346.1 & 13.8 & 61.0 \\
\hline & Mean & 2.6 & 64.0 & 248.8 & 2.8 & 57.3 & 1.7 & 64.2 & 58.9 & 3.1 & 55.8 & 1.9 & 67.0 & 259.0 & 6.5 & 55.3 \\
\hline $0 t 0$ & Mean & 10.1 & 74.5 & 170.2 & 10.0 & 68.1 & 8.6 & 73.5 & 36.0 & 10.7 & 65.1 & 9.1 & 78.4 & 168.3 & 12.8 & 68.1 \\
\hline
\end{tabular}

PD: Pinus densiflora Siebold \& Zucc., PK: Pinus koraiensis Siebold \& Zucc., LK: Larix kaempferi (Lamb.) Carrière., T: monthly mean temperature $\left({ }^{\circ} \mathrm{C}\right)$; RH: monthly mean relative humidity (\%); LI : monthly mean light intensity (lux)

Table 3

Differences in daily mean temperature and relative humidity between three study sites and weather stations from July 2015 to April 2017 determined by the Wilcoxon rank-sum test.

\begin{tabular}{llcc}
\hline Weather factor & \multicolumn{1}{c}{ Location } & $Z$ & $P$ \\
\hline \multirow{2}{*}{ Daily mean } & Site 1 vs Weather station & -1.632 & 0.103 \\
temperature $\left({ }^{\circ} \mathrm{C}\right)$ & Site 4 vs Weather station & -19.832 & 0.000 \\
& Site 6 vs Weather station & -19.650 & 0.000 \\
\hline \multirow{2}{*}{$\begin{array}{l}\text { Daily mean relative } \\
\text { humidity (\%) }\end{array}$} & Site 1 vs Weather station & -15.873 & 0.000 \\
& Site 4 vs Weather station & -21.66 & 0.000 \\
& Site 6 vs Weather station & -19.21 & 0.000 \\
\hline
\end{tabular}

\subsection{Comparison of light intensity between forest stands}

Figure 3 shows the comparison of mean monthly light intensity (lux) among the three conifer forest stands from July 2015 to April 2017. During autumn (September to November), the mean monthly light intensity was typically lower than those during other seasons, whereas it was relatively 


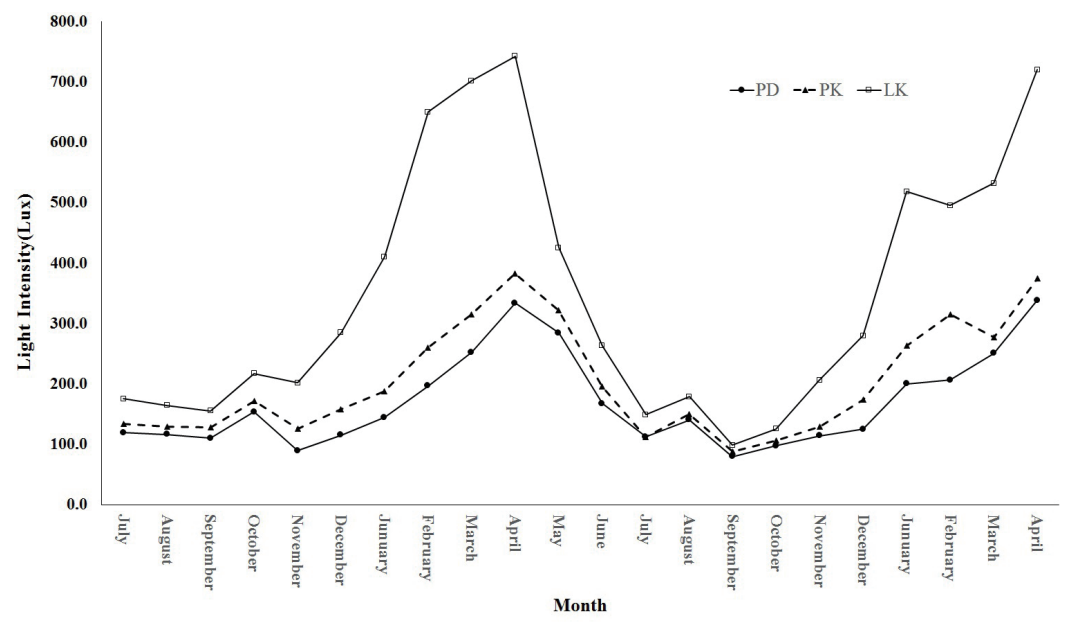

Fig. 3. Comparison of light intensity (lux) for three different sites during the study period. PD: Pinus densiflora Siebold \& Zucc., PK: Pinus koraiensis Siebold \& Zucc., LK: Larix kaempferi (Lamb.) Carrière.

higher in winter (November to February). In spring (March to May), the mean monthly light intensity was significantly higher than those during other seasons. The highest values were observed in LK trees (site 6) from December to May. These results indicate that PD and PK trees are evergreen coniferous trees, but for LK, leaves fall from the tree crown during winter, exposing the forest floor to sunlight.

\subsection{Meteorological characteristics of each forest stand}

\subsubsection{PD forest stand}

The meteorological analysis results of PD forest stands (sites 1 and 2) are shown in Fig. 4. Weather factors were measured from July 2015 to April 2017 at site 1 and from October 2015 to April 2017 at site 2. Analysis was conducted from October 2015 to April 2017. The mean temperatures at sites 1 and $2\left(9.1\right.$ and $9.2^{\circ} \mathrm{C}$, respectively), were similar, but site 1 had a higher mean maximum temperature $\left(16.3{ }^{\circ} \mathrm{C}\right)$ and a lower mean minimum temperature $\left(3.4{ }^{\circ} \mathrm{C}\right)$ than site 2 despite their close proximity $(53.6 \mathrm{~km})$. These results might reflect the characteristics of the forest stands where the HOBO data loggers were installed. The mean tree ages at the two sites (47 years for site 1 and 45 years for site 2) were similar, but the microclimate differed. This might be due to the differences in the tree density and altitude of the forest stands (Table 1). The mean relative humidity was higher at site $1(73.6 \%)$ than at site 2 , which likely reflects the fact that site 1 is adjacent to the valley and site 2 is located on the mountain ridge. The daily mean temperature difference (Wilcoxon rank-sum test: $Z=-0.507, P=0.612$ ) was not significant between the two sites; however, the differences in daily mean maximum temperature $(Z=-13.934, P=0.000)$, daily mean minimum temperature $(Z=-13.387, P=0.000)$, and daily mean relative humidity $(Z=-13.160, P=0.000)$ were significant (Table 4$)$. The similar mean temperature, despite the lower altitude of site 1, may reflect its southwest location and low tree density. 


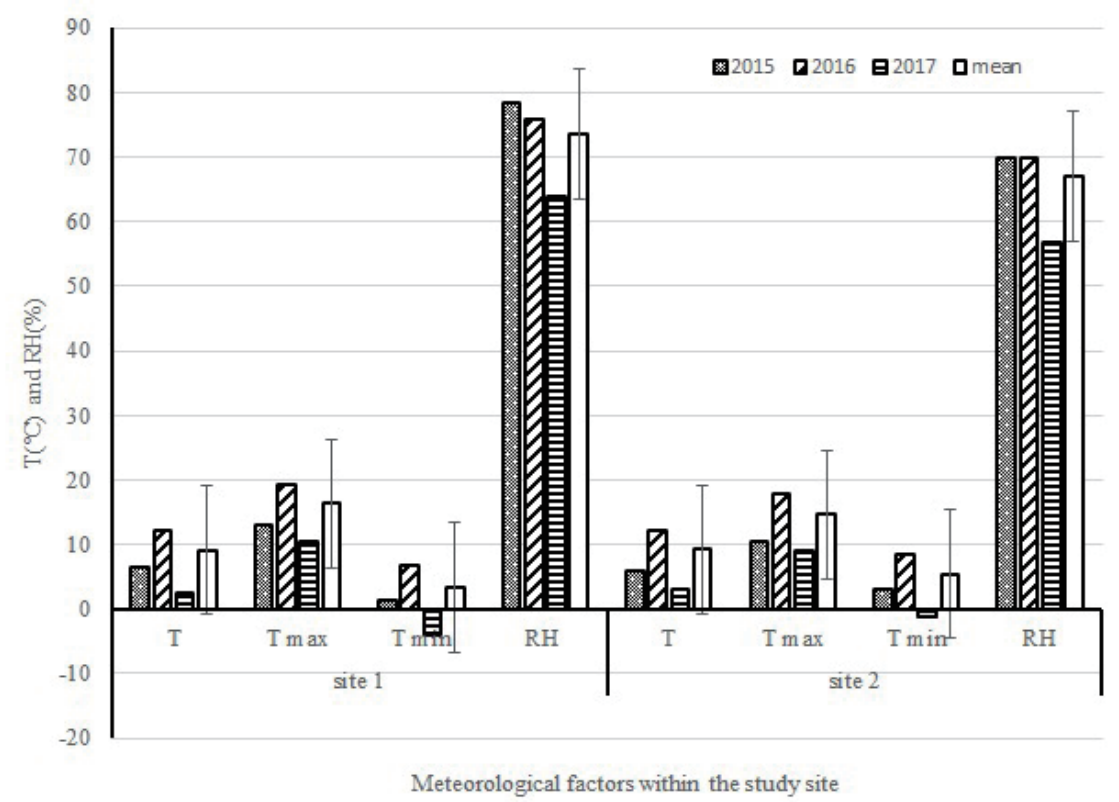

Fig. 4. Comparison of meteorological factors in two PD forest stand areas. T: monthly mean temperature $\left({ }^{\circ} \mathrm{C}\right)$; T max: monthly mean maximum temperature $\left({ }^{\circ} \mathrm{C}\right)$; $\mathrm{T}$ min: monthly mean minimum temperature $\left({ }^{\circ} \mathrm{C}\right)$; $\mathrm{RH}$ : monthly mean relative humidity.

Table 4

Differences in daily mean meteorological factors (mean \pm SD) of two PD forest stand sites from October 2015 to April 2017 determined by the Wilcoxon rank-sum test.

\begin{tabular}{lccrc}
\hline Meteorological factor & Site 1 & Site 2 & $Z$ & $P$ \\
\hline T mean $\left({ }^{\circ} \mathrm{C}\right)$ & $8.2887 \pm 9.48400$ & $8.3534 \pm 9.33793$ & -.507 & .612 \\
T max $\left({ }^{\circ} \mathrm{C}\right)$ & $15.3695 \pm 9.75187$ & $13.8158 \pm 9.78184$ & -13.934 & .000 \\
T min $\left({ }^{\circ} \mathrm{C}\right)$ & $2.6399 \pm 9.96053$ & $4.6072 \pm 9.49595$ & -13.387 & .000 \\
RH mean $(\%)$ & $73.2761 \pm 15.91822$ & $66.4216 \pm 19.86967$ & -13.160 & .000 \\
\hline
\end{tabular}

${ }^{*} \mathrm{~T}$ mean: daily mean temperature $\left({ }^{\circ} \mathrm{C}\right)$; $\mathrm{T}$ max: daily mean maximum temperature $\left({ }^{\circ} \mathrm{C}\right) ; \mathrm{T}$ min: daily mean minimum temperature $\left({ }^{\circ} \mathrm{C}\right)$; RH mean: daily mean relative humidity (\%)

\subsubsection{PK forest stand}

The meteorological factors of the PK forest stands (sites 3 and 4) were analyzed from July 2015 to April 2017 (Fig. 5). The mean, mean maximum, and mean minimum temperatures during the study period were higher at site $3\left(10.2,15.1\right.$, and $6.4{ }^{\circ} \mathrm{C}$, respectively). The mean relative humidity was lower at site 3 than at site 4 (70.8 and $73.5 \%$, respectively). The differences in daily mean temperature (Wilcoxon rank-sum test: $Z=-19.822, P=0.000$ ), daily mean maximum temperature $(Z=-20.172, P=0.000)$, daily mean minimum temperature $(Z=$ $-15.805, P=0.000)$, and daily mean relative humidity $(Z=-6.872, P=0.000)$ were significant between the two sites (Table 5). The tree density, slope, aspect, and tree age were very similar in the two sites (Table 1); therefore, the differences in meteorological factors between the sites may be due to latitude differences. However, longer-term studies are required for a more accurate interpretation. 


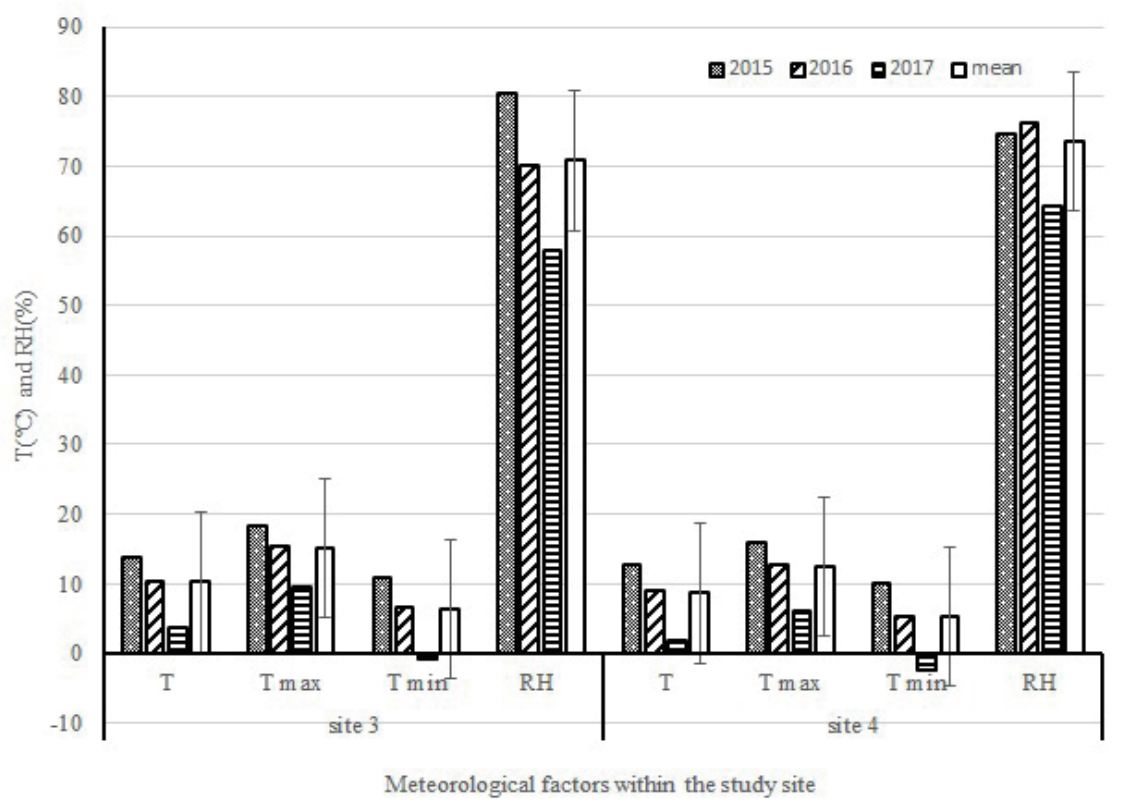

Fig. 5. Comparison of meteorological factors in two PK forest stand areas. T: monthly mean temperature $\left({ }^{\circ} \mathrm{C}\right) ; \mathrm{T}$ max: monthly mean maximum temperature $\left({ }^{\circ} \mathrm{C}\right)$; $\mathrm{T}$ min: monthly mean minimum temperature $\left({ }^{\circ} \mathrm{C}\right)$; $\mathrm{RH}$ : monthly mean relative humidity.

Table 5

Differences in daily mean meteorological factors (mean \pm SD) of two PK forest stand sites from October 2015 to April 2017 determined by the Wilcoxon rank-sum test.

\begin{tabular}{lccrc}
\hline Meteorological factor & Site 3 & Site 4 & $Z$ & $P$ \\
\hline T mean $\left({ }^{\circ} \mathrm{C}\right)$ & $10.5372 \pm 9.42803$ & $8.5048 \pm 9.96397$ & -19.822 & .000 \\
T max $\left({ }^{\circ} \mathrm{C}\right)$ & $15.4280 \pm 9.67077$ & $12.2358 \pm 9.95091$ & -20.172 & .000 \\
T min $\left({ }^{\circ} \mathrm{C}\right)$ & $6.7862 \pm 9.73432$ & $5.1933 \pm 10.30400$ & -15.805 & .000 \\
RH mean $(\%)$ & $71.6054 \pm 18.10071$ & $73.4788 \pm 18.78705$ & -6.872 & .000 \\
\hline
\end{tabular}

${ }^{*} \mathrm{~T}$ mean: daily mean temperature $\left({ }^{\circ} \mathrm{C}\right)$; $\mathrm{T}$ max: daily mean maximum temperature $\left({ }^{\circ} \mathrm{C}\right) ; \mathrm{T}$ min: daily mean minimum temperature $\left({ }^{\circ} \mathrm{C}\right)$; RH mean: daily mean relative humidity (\%)

\subsubsection{LK forest stand}

Meteorological factors for the LK forest stand were measured from July 2015 to April 2017 for site 6 and from August 2016 to April 2017 for site 5. Meteorological data from August 2016 to April 2017 were analyzed (Fig. 6). During the study period, the mean, mean maximum, and mean minimum temperatures were approximately $1{ }^{\circ} \mathrm{C}$ lower at site 5 than at site 6 . The mean relative humidity was slightly higher at site $6(78.2 \%)$. The differences in daily mean temperature (Wilcoxon rank-sum test: $Z=-14.085, P=0.000$ ), daily mean maximum temperature $(Z=-13.252, P=0.000)$, daily mean minimum temperature $(Z=-14.085, P=0.000)$, and daily mean relative humidity $(Z=-13.226, P=0.000)$ were significant between the two sites (Table 6). Sites 5 and 6 are both located in the eastern part of the Korean peninsula, which has an oceanic climate (Fig. 1) with a similar slope direction. However, the meteorological differences can be explained by the higher altitude and latitude of site 5 . 


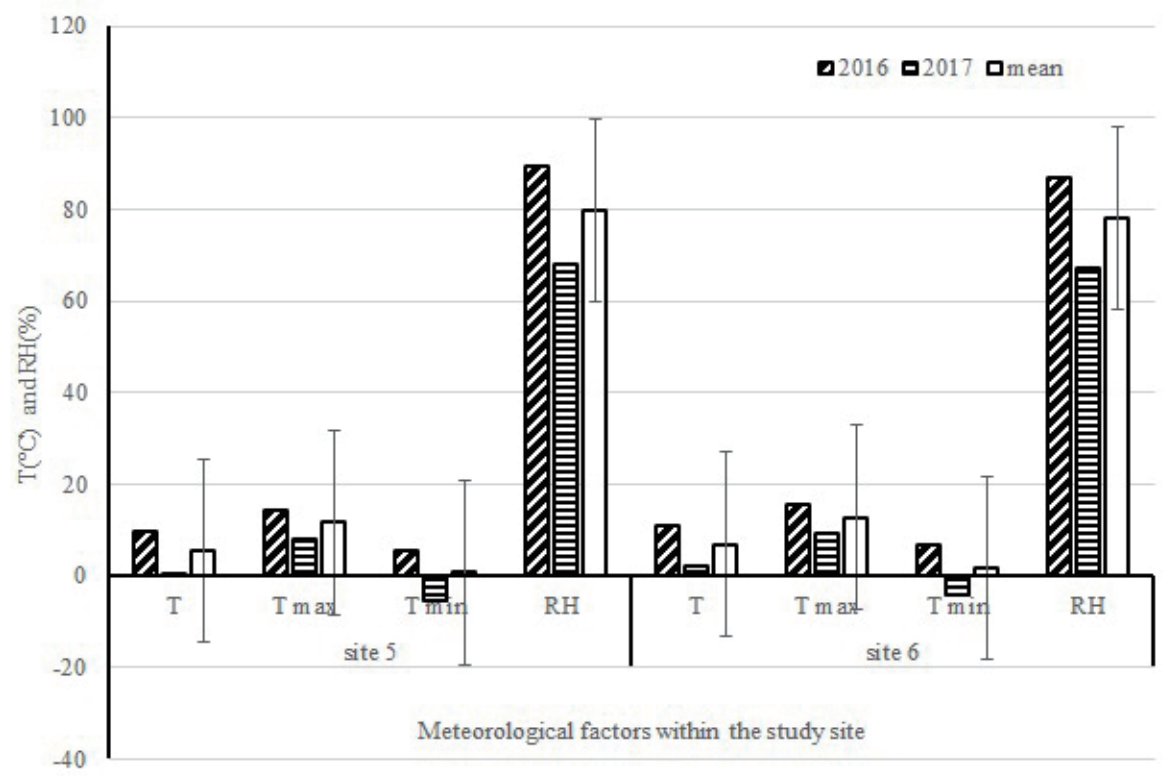

Fig. 6. Comparison of meteorological factors between two LK forest stand areas. T: monthly mean temperature $\left({ }^{\circ} \mathrm{C}\right)$; T max: monthly mean maximum temperature $\left({ }^{\circ} \mathrm{C}\right)$; $\mathrm{T}$ min: monthly mean minimum temperature $\left({ }^{\circ} \mathrm{C}\right) ; \mathrm{RH}$ : monthly mean relative humidity.

Table 6

Differences in daily mean meteorological factors (mean \pm SD) of two LK forest stand sites from October 2015 to April 2017 determined by the Wilcoxon rank-sum test.

\begin{tabular}{lcccc}
\hline Meteorological factors & Site 5 & Site 6 & $Z$ & $P$ \\
\hline T mean $\left({ }^{\circ} \mathrm{C}\right)$ & $5.3492 \pm 9.18295$ & $11.1285 \pm 7.9824$ & -14.085 & .000 \\
T max $\left({ }^{\circ} \mathrm{C}\right)$ & $11.3148 \pm 8.98385$ & $15.8434 \pm 7.50459$ & -13.252 & .000 \\
T min $\left({ }^{\circ} \mathrm{C}\right)$ & $0.4686 \pm 9.94217$ & $6.8064 \pm 8.60463$ & -14.085 & .000 \\
RH mean $(\%)$ & $80.3064 \pm 16.52890$ & $66.1390 \pm 19.10250$ & -13.266 & .000
\end{tabular}

${ }^{*} \mathrm{~T}$ mean: daily mean temperature $\left({ }^{\circ} \mathrm{C}\right) ; \mathrm{T}$ max: daily mean maximum temperature $\left({ }^{\circ} \mathrm{C}\right) ; \mathrm{T}$ min: daily mean minimum temperature $\left({ }^{\circ} \mathrm{C}\right)$; RH mean: daily mean relative humidity (\%)

\section{Conclusions}

We analyzed the meteorological characteristics of three types of coniferous forest in Korea. The meteorological data were collected from the HOBO data logger installed at the forest stands and weather stations adjacent to the study sites to compare the characteristics of forest land and nonforest land. The differences in daily mean temperature and relative humidity derived using the Wilcoxon rank-sum test are shown in Table 3. Meteorological differences between forest sites and nonforest areas (weather stations) are significant, except for the daily mean temperature at site 1 , and reflect forest characteristics such as forest canopy and vegetation type. The difference in light intensity among three conifer forest stands indicate that the PD and PK trees are evergreen coniferous trees, but in the case of LK, leaves fall from the tree crown during winter, exposing the forest floor to sunlight. 
A comparison of the microclimate characteristics of three forest stands showed that the maximum temperature in a forest increases owing to the effect of altitude and varies with the direction of the slope. ${ }^{(24)}$ The climatic conditions at the bottom of the tree canopy affect the minimum and maximum temperatures and depend on the forest type and dominant tree species. ${ }^{(25)}$ Moreover, the climatic characteristics of forest land vary depending on the altitude difference. ${ }^{(26)}$ Our results reflect these findings and indicate that, even if the same tree species is planted in a forest area, the microclimate effects will vary depending on the environmental characteristics of the forest stand, such as elevation, slope, and latitude. To more accurately analyze these environmental characteristics to better understand the climatic characteristics of individual forest stands, a more long-term monitoring effort is required. Also, it is necessary to investigate the effect of microclimate on forest growth in Korea. In future work, the differences in meteorological characteristics between forest land and nonforest land should be analyzed in more detail according to location (e.g., slope, aspect, and altitude), forest canopy type (e.g., tree species and dominant tree species), and forest type (e.g., tree density and tree age).

\section{References}

1 T. U. Kim, J. H. Sung, T. S. Kwon, J. H. Chun, and M. Y. Shin: J. Korean. Soc. For. Sci. 102 (2013) 437. http:// www.koreascience.or.kr/article/JAKO201308156245702.page

2 A. A. Nuruddin and L. Tokiman: Asian. J. Plant. Sci. 4 (2005) 144. https://www.researchgate.net/ publication/26564074_Air_and_Soil_Temperature_Characteristics_of_Two_Sizes_Forest_Gap_in_Tropical_ Forest

3 M. B. Johansson, B. Berg, and V. Meentemeyer: Can. J. Bot. 73 (1995) 1509. https://www.nrcresearchpress. com/doi/abs/10.1139/b95-163\#.XSXEEeR7k6Y

4 D. B. Zobel, A. Mckee, G. M. Hawk, and C. T. Dryness: Ecol. Monogr. 46 (1976) 135. https://www.jstor.org/ stable/1942248?seq=1\#metadata_info_tab_contents

5 J. Chen and J. F. Franklin: Clim. Res. 8 (1997) 21. https://www.int-res.com/abstracts/cr/v08/n1/p21-34/

6 R. H. Waring and W. H. Schlesinger: Forest Ecosystems: Concepts and Management (Academic Press, Orland, 1985) p. 75

7 X. Ming, C. Jiquan, and B. L. Brookshire: Clim. Res. 8 (1997) 209. https://www.int-res.com/abstracts/cr/v08/ n3/p209-223/

8 T. R. Oke: Boundary Layer Climates (Taylor \& Francies e-Library, 2002) p. 416

9 G. Aussenac: Ann. For. Sci. 57 (2000) 287. https://www.afs-journal.org/articles/forest/abs/2000/03/f0310/ f0310.html? $\mathrm{mb}=0$

10 R. Geiger, R. H. Aron, and P. Todhunter: The Climate Near the Ground (Rowman \& Littlefield Publishers., Inc., Lanham, 2003) p. 315.

11 C. S. B. Grimmond, S. M. Robeson, and J. T. Schoof: Clim. Res. 15 (2000) 137. https://www.int-res.com/ abstracts/cr/v15/n2/p137-149/

12 R. Lee: Forest Microclimatology (Columbia University Press, New York, 1978) p. 276.

13 T. R. Rambo and M. P. North: For. Ecol. Manage. 257 (2009) 435. https://www.sciencedirect.com/science/ article/pii/S0378112708006981

14 R. H. Whittaker: Communities and Ecosystems (MacMillan Publishing Co., Inc., London and New York, 1975) 2nd ed., p. 165.

15 R. J. Davies-Colley, G. W. Payne, and M. V. Elswijk: N. Z. J. Ecol. 24 (2000) 111. https://www.jstor.org/ stable/24054666?seq=1\#page_scan_tab_contents

16 M. F. Kirschbaum: Tree. Physiol. 20 (2000) 309. https://academic.oup.com/treephys/article/20/5-6/309/1691339

17 P. Datta and S. Das: Spat. Inf. Res. 27 (2019) 475. https://link.springer.com/ article/10.1007\%2Fs41324-019-00250-8

18 N. Kayet, K. Pathak, A. Chakrabarty, and S. Sahoo: Spat. Inf. Res. 24 (2016) 515. https://link.springer.com/ article/10.1007\%2Fs41324-016-0049-3

19 J. B. Friedrich, F. May, and A. Huth: Biogeosciences Discussion 15 (2018) 1795. https://www.biogeosciences. net/15/1795/2018/ 
20 Korea Forest Service: A Statistical Yearbook of Forestry (KFS, Seoul, 2017) p. 78.

21 Korea Meteorological Administration: National Climate Data Service System. (2018) http://www.kma.go.kr/ info_open/public_data/guidepage.jsp (accessed 2018)

22 H. S. Hwang, J. K. Lee, T. K. Eom, and S. J. Rhim: For. Sci. Technol. 13 (2017) 142. https://www.tandfonline. com/doi/full/10.1080/21580103.2017.1342276

23 P. B. Violeta, P. K. Milun, V. G. Zoran, R. T. Jovana, T. V. Nebojša, and G. M. Zoran: Thermal Science 19 (2015) 415. http://www.doiserbia.nb.rs/img/doi/0354-9836/2015/0354-98361500116B.pdf

24 J. Ferrez, A. C. Davison, and M. Rebetez: Agric. For. Meteorol. 151 (2011) 992. https://www.sciencedirect. com/science/article/pii/S0168192311000864

25 V. Renaud, J. L. Innes, M. Dobbertin, and M. Rebetez: Theor. Appl. Climatol. 105 (2011) 119. https://ink. springer.com/article/10.1007/s00704-010-0361-0

26 H. M. Chae, H. J. Lee, S. S. Lee, Y. K. Cheong, G. J. Um, B. Mark, and N. Patrock: J. Mt. Sci. 9 (2012) 613. https://link.springer.com/article/10.1007/s11629-012-2347-0

\section{About the Authors}

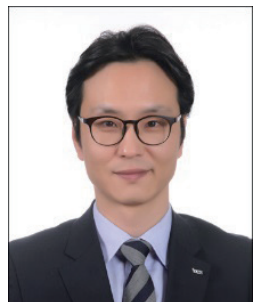

Byoung koo Choi received his B.S. and M.S. degrees from Kangwon National University, Republic of Korea, in 2002 and 2004, respectively, and his Ph.D. degree from Mississippi State University, USA, in 2011. From 2014 to 2015, he was a research scientist at the National Institute of Ecology, Republic of Korea. Since 2015, he has been an assistant professor at Kangwon National University. His research interests include eco-hydrology, watershed management, and forestry BMPs. (bkchoi@kangwon.ac.kr)

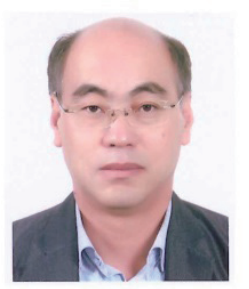

Hee Mun Chae received his B.S., M.S., and Ph.D. degrees from Kangwon National University, Republic of Korea, in 1989, 1995, and 2003, respectively. From 2009 to 2012, he was a research scientist at the Korea Research Institute on Climate Change, Republic of Korea. Since 2012, he has been an associate professor at Kangwon National University. His research interests include microclimate and forest fire management. (cheemun@kangwon.ac.kr) 